\title{
Karakter Fisik dan Aktivitas Antibakteri Nanopartikel Perak Hasil Green Synthesis Menggunakan Ekstrak Air Daun Sendok (Plantago major L.)
}

\section{Physical Characteristics and Antibacterial Activity of Silver Nanoparticle from Green Synthesis Process using Aqueous Extract of Plantago major $L$.}

\author{
Komang Tri Aksari Dewi ${ }^{1}$, Kartini ${ }^{1}$, Johan Sukweenadhi ${ }^{2}$, Christina Avanti ${ }^{{ }^{*}}$ \\ ${ }^{1}$ Fakultas Farmasi Universitas Surabaya, Surabaya, Indonesia \\ ${ }^{2}$ Fakultas Teknobiologi Universitas Surabaya, Surabaya, Indonesia
}

\begin{abstract}
ABSTRAK
Nanopartikel perak telah diteliti pemanfaatannya untuk terapi penyembuhan luka, dan ekstrak air daun sendok (Plantago major L.) juga diteliti aktivitasnya sebagai antibakteri dan penyembuhan luka. Penelitian ini bertujuan untuk mendapatkan nanopartikel perak (AgNPs) melalui jalur green synthesis menggunakan ekstrak air daun sendok (Plantago major L.). Tahap awal penelitian dilakukan dengan melakukan optimasi terhadap tiga konsentrasi ekstrak air Daun Sendok, yaitu 0,125\%, 0,25\% dan 0,5\% dan tiga suhu sintesis yaitu $60^{\circ} \mathrm{C}, 70^{\circ} \mathrm{C}$, dan $80^{\circ} \mathrm{C}$. Terbentuknya AgNPs dikonfirmasi menggunakan spektrofotometer UV-Vis yang menunjukkan puncak pada panjang gelombang $445 \mathrm{~nm}$. Nanopartikel perak yang terbentuk dikarakterisasi dengan Dynamic Light Scattering (DLS Nano), Scanning Electron Microscope (SEM) dan X-Ray Diffraction (XRD). Aktivitas antibakteri AgNPs diuji terhadap tiga strain bakteri, yaitu Staphylococcus aureus, Eschericia coli, dan Pseudomonas aeruginosa ditentukan dengan metode difusi menggunakan paper disc. Hasil optimasi menunjukkan konsentrasi ekstrak tanaman $0,25 \%$ dengan suhu sintesis $70^{\circ} \mathrm{C}$ merupakan kombinasi optimum untuk menghasilkan AgNPs terbaik, dilihat dari parameter organoleptis berupa kilau perak yang dihasilkan, rendemen tertinggi dengan bobot $9,13 \mathrm{mg}$ dan ukuran partikel terkecil yaitu 129,20 nm dengan nilai PDI (Polydispersity Index) 0,25. Morfologi AgNPs menunjukkan bentuk sferis dan kristalisasi AgNPs menunjukkan pola difraktogram yang serupa dengan standar perak. Hasil pengujian aktivitas antibakteri menunjukkan AgNPS memiliki aktivitas antibakteri yang lebih baik dari perak nitrat dan setara dengan antibiotik pembandingnya yaitu Gentamicin Sulfat untuk bakteri gram negatif dan kloramfenikol untuk gram positif.
\end{abstract}

\section{ARTICLE HISTORY}

Received: August 2018 Revised: October 2018 Accepted: April 2019

Kata kunci: green synthesis; nanopartikel perak; karakterisasi; aktivitas antibakteri; daun sendok; Plantago major L.

\begin{abstract}
Silver nanoparticles have been studied for its application in wound healing therapy, while aqueous extract of Plantago major L has been studied also for its antibacterial and wound healing activity. This study aimed to obtain silver nanoparticles (AgNPs) through a green synthesis pathway using aqueous extract of Plantago major $\mathrm{L}$. The initial study was performed to optimize the three concentration points of Plantago major L. aqueous extract, namely $0.125 \%, 0.25 \%$ and $0.5 \%$ and three synthetic temperature points $(60$ ${ }^{\circ} \mathrm{C}, 70{ }^{\circ} \mathrm{C}$, and $80^{\circ} \mathrm{C}$ ). The formation of AgNPs were confirmed using a UV-Vis spectrophotometer which shows a peak at a wavelength of $445 \mathrm{~nm}$. The obtained silver nanoparticles were then characterized using Dynamic Light Scattering (DLS Nano), Scanning Electron Microscope (SEM) dan X-Ray Diffraction (XRD). The study showed that the extract concentration of $0.25 \%$ with an optimum temperature of 70 ${ }^{\circ} \mathrm{C}$ was the optimal combination to produce the best AgNPs, based on the organoleptic parameters (as the color of silver was produced), the highest yield with weight of $9.13 \mathrm{mg}$ and particle size of 129.20 $\mathrm{nm}$ with Polydispersity Index (PDI) of 0.25 . The morphology of AgNPs showed the spherical shape and the crystallization of AgNPs showed a diffractogram pattern similar to the silver standard using X-Ray Diffraction (XRD). Antibacterial activity of AgNPs was tested against three bacterial strains, namely Staphylococcus aureus, Escherichia coli, and Pseudomonas aeruginosa and was measured with diffusion method using paper disc. The antibacterial activity testing showed that AgNPS has better antibacterial activity than silver nitrate and is equivalent to its comparative antibiotics, gentamicin sulfate for gramnegative bacteria and Chloramphenicol for gram-positive bacteria.
\end{abstract}

Key words: green synthesis; silver nanoparticles; characterization; antibacterial activity; Plantago major $L$.

*corresponding author

Email: c_avanti@staff.ubaya.ac.id 


\section{PENDAHULUAN}

Nanoteknologi merupakan ranah yang penting pada bidang penelitian modern. Pendekatan nanoteknologi berkaitan dengan desain, sintesis, dan manipulasi yang dilakukan untuk memperoleh struktur partikel dengan ukuran berkisar 1-1000 nm (Kim et al., 2016) yang kemudian disebut dengan partikel berukuran nano atau nanopartikel. Nanopartikel memiliki cakupan aplikasi yang sangat luas di berbagai bidang seperti kesehatan, kosmetik, makanan, kesehatan lingkungan, ilmu biomedis, industri kimia, elektronik, mekanik, optik, industri penerbangan, dan masih banyak lagi (S Iravani et al., 2014). Nanopartikel senyawa logam saat ini mendapatkan perhatian yang sangat besar karena aplikasinya yang sangat besar dalam berbagai bidang, diantaranya bidang biomedisinal (Yu-jin et al., 2016), seperti pada studi yang memaparkan tentang penggunakan nanopartikel perak sebagai agen terapi luka. Pengobatan topikal dengan basis nanopartikel perak telah digunakan secara luas dalam pengobatan infeksi pada luka terbuka dan pada ulkus kronis (Mishra et al., 2008). Studi serupa juga dilakukan oleh Jun Tian et al tentang pemanfaatan nanopartikel perak pada terapi wound healing, dimana dari hasil observasi yang dilakukan menunjukkan adanya percepatan kesembuhan pada luka yang diterapi dengan nanopartikel perak (Tian et al., 2007).

Pemanfaatan nanopartikel yang besar dalam bidang biomedik, menciptakan tantangan tersendiri dalam metode sintesisnya. Metode sintesis nanopartikel didasarkan pada tiga pendekatan proses yaitu secara kimia, fisika, dan biologi (Iravani et al., 2014). Metode fisikokimia pada penerapannya menggunakan senyawa kimia yang beresiko menimbulkan adverse effects pada aplikasi di bidang medis (Parashar et al., 2009). Dewasa ini, sintesis nanopartikel secara biologi lebih disukai dibandingkan metode fisikokimia, karena dinilai lebih memiliki banyak keuntungan, diantaranya : lebih ecofriendly (Kim, 2015), non-toxic, lebih reproducible, lebih mudah di-scale up, dan morfologinya lebih baik (Kim et al., 2016). Sumber sintesis nanopartikel secara biologi adalah mikroorganisme dan tanaman. Namun demikian, dalam prakteknya penggunaan tanaman untuk sintesis nanopartikel lebih disukai dibandingkan dengan mikroorganisme karena berbagai alasan, diantaranya: langkah yang lebih sederhana, lebih cepat, lebih cost-effective, lebih biocompatible sehingga lebih aplikatif untuk digunakan dalam ranah medis. Hampir semua komponen dalam tanaman seperti protein, asam amino, asam organik, vitamin, dan metabolit sekunder seperti flavonoid, alkaloid, polifenol, terpenoid, komponen heterosiklik, dan polisakarida, mempunyai fungsi signifikan dalam mereduksi garam logam, bertindak sebagai capping dan stabilizing agent dalam sintesis nanopartikel (Kim et al., 2016). E-ISSN 2477-0612
Penelitian ini menggunakan daun sendok (Plantago major L.) sebagai sumber green synthesis nanopartikel perak. Pemilihan daun sendok didasarkan pada kandungan komponen aktif biologi yang dimiliki tanaman ini memiliki peran yang penting dalam sintesis nanopartikel, yaitu dapat mereduksi garam logam, dan bertindak sebagai capping agent dan stabilizing agent. Selain itu pemilihan daun sendok juga didasarkan pada pemanfaatannya yang luas di bidang biomedisinal seperti: antiinflamasi, antibakteri, antijamur, antioksidan, antitumor, immunomodulating, antiulcerogenic, dan juga aktivitas wound healing (Mahmood, 2006). Mengacu pada studi yang dilakukan oleh Mahmood et al berjudul "Wound Healing Activities of Plantago mayor Leaf Extract in rats" yang menunjukkan adanya aktivitas penyembuhan luka dari ekstrak air daun sendok pada percobaan yang dilakukan pada tikus, diharapkan dengan pemanfaatannya sebagai sumber sintesis nanopartikel, daun sendok yang digunakan juga dapat memberikan efek yang sinergis dengan nanopartikel perak yang dihasilkan dalam memberikan efek antibakteri dan penyembuhan luka. Pemilihan logam perak sendiri didasarkan pada kemanfaatannya di bidang medis. Nanopartikel perak telah lama digunakan pada berbagai masalah antibakteri, juga sebagai antikanker, anti-inflamasi, dan wound treatment (Ahmed, 2010).

Dalam proses sintesis nanopartikel menggunakan tanaman, terdapat beberapa parameter yang dapat mempengaruhi yield yang diperoleh yaitu kandungan yang dimiliki katalis (dalam hal ini adalah tanaman yang digunakan), media tempat reaksi berlangsung, dan kondisi reaksi (misalnya: pelarut, stabilizer, suhu) (Keat et al., 2015). Proses awal sintesis nanopartikel perak pada penelitian ini dimulai dengan optimasi parameter sintesis. Dalam penelitian ini, parameter yang dioptimasi adalah konsentrasi ekstrak air tanaman daun sendok dan suhu sintesis yang digunakan. Komponen parameter yang diukur dalam proses optimasi ini adalah, parameter organoleptis berupa kilau warna perak rendemen yang dihasilkan dari masing-masing kombinasi konsentrasi ekstrak daun sendok dan suhu sintesis, bobot rendemen, ukuran dan distribusi ukuran partikel dari rendemen nanopartikel perak yang dihasilkan, menggunakan instrumen Dynamic Light Scattering-Nanoparticle (DLS-Nano). Rendemen nanopartikel perak hasil sintesis menggunakan kombinasi konsentrasi ekstrak dan suhu sintesis terbaik kemudian dikarakterisasi menggunakan Scanning Electron microscopy (SEM) untuk mengamati bentuk morfologi nanopartikel perak yang terbentuk, dan $X$-ray Diffraction (XRD) untuk memastikan kandungan senyawa perak sebagai logam spesifik yang terbentuk dari hasil sintesis nanopartikel ini. Lebih jauh rendemen AgNPs diuji aktivitas antibakterinya dengan metode difusi, yaitu menggunakan paper disc. Bakteri uji yang digunakan adalah Staphylococcus aureus, Pseudomonas aeruginosa, dan Escherichia coli. 
Hasil penelitian ini diharapkan dapat memberikan informasi mengenai karakteristik senyawa nanopartikel perak yang dihasilkan melalui jalur green synthesis menggunakan ekstrak air tanaman daun sendok (Plantago mayor L.), konsentrasi ekstrak dan suhu sintesis optimum yang digunakan pada saat sintesis, serta aktivitas antibakteri dari nanopartikel perak yang dihasilkan dibandingkan dengan ekstrak daun sendok dan senyawa perak yang diketahui memiliki aktivitas antibakteri. Hasil penelitian ini dapat digunakan sebagai referensi untuk pengembangan produk berbasis nanopartikel perak.

\section{METODE}

\section{Bahan Tanaman}

Bahan tanaman yang digunakan dalam penelitian ini adalah bagian helai daun tanpa tangkai daun dari tanaman daun sendok (Plantago major L.) sesuai hasil determinasi pada Pusat Informasi dan Pengembangan Obat Tradisional (PIPOT) Universitas Surabaya. Helai daun ini kemudian dikeringkan dengan cara dianginanginkan, dihaluskan dengan mesin blender dan diayak dengan mesh 20 .

\section{Bahan Kimia dan Mikroorganisme}

Bahan yang digunakan, yaitu garam logam $\mathrm{AgNO}_{3}$ (Merck), natrium hidroksida (Merck), aquabidestilata (FF Ubaya). Bakteri Staphylococcus aureus, bakteri Pseudomonas aeruginosa, bakteri Escherichia coli, media nutrient agar, media antibiotic agar I, media Vogel Johnson's Agar, pereaksi gentian violet, kalium iodida, pereaksi fuchsin, $\mathrm{NaCl} 0,9 \%$ (Merck).

\begin{abstract}
Alat
Ultrasonic bath (Branson, USA), spektrofotometer UVVis (Thermo Scientific, USA), centrifuge $2000 \mathrm{rpm}$ (Hettich, Germany), centrifuge $11.000 \mathrm{rpm}$ (Thermo Scientific, USA), scanning electron microscopy (Jeol JM6510, Japan), dynamic light scattering-nanoparticle (Beckman Coulter, USA), $x$ ray difraction (Rigaku Ultima IV, Japan), neraca analitik (Sartorius BL210s, Germany), blender (Hitachi, Japan), stopwatch (Alba, UK), dan alat-alat gelas laboratorium.
\end{abstract}

\section{Penyiapan Ekstrak Air Daun Sendok}

Helai daun sendok tanpa tangkai dicuci bersih, dikeringkan dengan diangin-anginkan. Kemudian daun sendok yang telah kering dihaluskan dengan blender hingga menjadi serbuk, lalu diayak dengan menggunakan pengayak mesh 20. Hasil dari ayakan ini kemudian disebut serbuk simplisia. Pembuatan ekstrak air daun sendok dilakukan dengan menggunakan metode Ultrasound Assisted Extraction (UAE). Pertama-tama, serbuk simplisia daun sendok ditimbang 10,0 gram. Ditambahkan air sebanyak $80 \mathrm{ml}$. Penambahan air dilakukan sedikit demi sedikit sampai serbuk terbasahi semua dan terendam. Kemudian diekstraksi dengan bantuan UAE selama 20 menit. Saring ekstrak hasil UAE dengan corong Buchner, ampas yang diperoleh ditambah lagi dengan aqua demineralisata (aquadem) sebanyak 20 $\mathrm{ml}$ lalu disaring ke dalam labu ukur yang sama, kemudian ditambahkan aquadem sampai 100,0 ml (setara dengan 100.000 bpj serbuk daun). Untuk selanjutnya larutan ini disebut sebagai ekstrak induk. Ekstrak induk dilakukan pengenceran dengan konsentrasi setara $0,125 \% ; 0,25 \%$ dan $0,5 \%$, hasil pengenceran ini kemudian disebut sebagai ekstrak uji.

\section{Proses Sintesis Nanopartikel Perak}

Ekstrak uji masing-masing konsentrasi ditambahkan AgNO3 $1 \mathrm{mM}$ dengan pengadukan. Setelah didapatkan campuran homogen ekstrak uji dan larutan garam logam AgNO3, lalu dipanaskan dengan pengadukan pada masing-masing suhu sintesisnya $\left(60,70,80^{\circ} \mathrm{C}\right)$ selama 60 menit. Larutan ini diamati absorbansinya setiap 15 menit $\left(\mathrm{t}_{0} ; \mathrm{t}_{15} ; \mathrm{t}_{30} ; \mathrm{t}_{45} ; \mathrm{t}_{60}\right)$ dengan spektrofotometer, untuk memantau terbentuknya nanopartikel perak. Setelah 60 menit, ditambahkan $\mathrm{NaOH}$ 0,2 $\mathrm{M}$ tetes demi tetes sambil diamati adanya perubahan warna dan terus diaduk tanpa pemanasan. Diamati perubahan warna yang terjadi, yang mengindikasikan terbentuknya nanopartikel perak, yaitu dari kuning muda menjadi coklat kemerahan. Amati absobansi larutan setelah penambahan $\mathrm{NaOH}$. Purifikasi nanopartikel perak dilakukan dengan sentrifugasi pada 2000 rpm selama 10 menit, untuk menghilangkan pengotor yang ada. Supernatan hasil purifikasi disentrifugasi pada $11.000 \mathrm{rpm}$ selama 15 menit untuk pengumpulan nanopartikel perak. Hasil berupa pellet dicuci beberapa kali dengan air steril. Partikel yang telah dicuci, disimpan semalaman, diangin-anginkan, dan kemudian akan didapat partikel dengan bentuk serbuk yang memadat. Rendemen hasil nanopartikel perak kemudian digunakan untuk tahap karakterisasi dan pengujian aktivitas antibakteri (Kim, 2015).

\section{Karakterisasi Nanopartikel Perak}

Senyawa yang diperoleh dari hasil sintesis nanopartikel perak menggunakan ekstrak air daun sendok kemudian dikarakterisasi pada beberapa parameter, yaitu organoleptis, rendemen diamati karakterisitik warna dan konsistensinya secara visual. Absorbansi larutan sintesis diamati seiring pertambahan waktu untuk mengkonfirmasi terbentuknya nanopartikel perak menggunakan instrumen Spectrofotometer UvVIS. Ukuran dan distribusi ukuran partikel rendemen nanopartikel perak diuji menggunakan instrumen Dynamic Light Scattering-Nanoparticle (DLS-Nano). Morfologi rendemen dianalisa menggunakan instrumen Scanning Electron Spectrocopy (SEM) dan kandungan senyawa perak pada rendemen dianalisa menggunakan instrumen X-Ray Difraction (X-RD) yang akan menunjukkan pola difragtogram spesifik. 

Penentuan Aktivitas Antibakteri dengan Metode
Paper Disc

Bakteri uji yang digunakan untuk penelitian ini adalah Staphylococcus aureus dari golongan bakteri gram positif, bakteri Escherichia coli dan Pseudomonas aeruginosa dari golongan bakteri gram negatif. Bakteri yang digunakan diidentifikasi terlebih dahulu sebelum digunakan dalam pengujian daya antibakteri. Media yang digunakan untuk pembenihan bakteri adalah media Antibiotic Medium I (AM), media Nutrient Agar (NA), serta media Vogel Johnson's Agar (VJA) dan telurit. Diambil $400 \mu \mathrm{L}$ suspensi bakteri dan ditambahkan ke dalam $40.0 \mathrm{~mL}$ media Antibiotic Medium I steril yang telah dicairkan dengan suhu $\pm 40^{\circ} \mathrm{C}$. Dikocok hingga homogen dan segera dituangkan ke dalam cawan petri steril secara merata sebelum media memadat. Diamkan pada suhu ruangan sampai media memadat. Setelah agar media memadat, paper disc steril diambil secara aseptis dan diletakkan di atas permukaan medium agar dalam cawan petri.
Untuk pengujian, rendemen nanopartikel perak dilarutkan dengan aqua demineralisata steril, hingga membentuk sistem koloidal. Untuk pengujian antibakteri terhadap gram positif, diambil larutan nanopartikel perak konsentrasi 250 ppm, sedangkan, untuk pengujian terhadap bakteri gram negatif nanopartikel yang diambil adalah 100 ppm. Larutan pembanding terdiri dari ekstrak air daun sendok dan juga larutan garam logam $\mathrm{AgNO}_{3}$ $1 \mathrm{mM}$ dengan konsentrasi yang sama yang digunakan untuk sintesis nanopartikel perak, kontrol positif berupa larutan antibiotik Kloramfenikol 250 ppm untuk pengujian terhadap bakteri gram positif dan Gentamicin sulfat 100 ppm untuk pengujian terhadap bakteri gram negatif, dan kontrol negatif berupa aquabidestilata steril. Masing-masing sampel uji diteteskan di atas paper disc. Cawan petri didiamkan selama 30 menit, kemudian dibungkus tanpa dibalik dan diinkubasi pada suhu $37^{\circ} \mathrm{C}$ selama 48 jam. Setelah 48 jam cawan petri dikeluarkan dari dalam inkubator kemudian diamati dan diukur zona bening di sekitar paper disc dengan menggunakan jangka sorong. Dilakukan tiga kali pengukuran dari arah berbeda pada diameter terluar daerah bening di sekitar paper disc. Pengujian diulangi 2 replikasi.

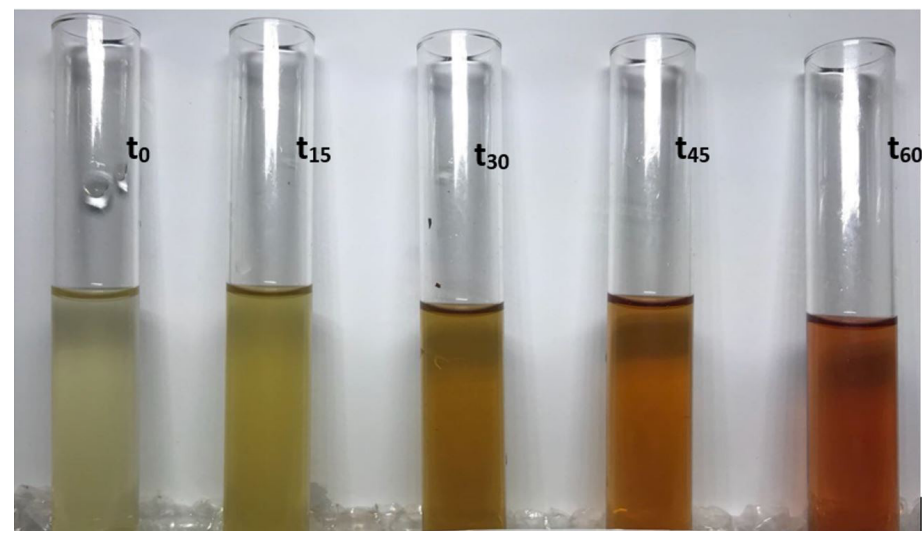

Gambar 1. Perubahan warna larutan seiring pertambahan waktu pemanasan pada proses sintesis nanopartikel perak menggunakan ekstrak air daun sendok dengan konsentrasi $0,25 \%$ suhu $70^{\circ} \mathrm{C}$

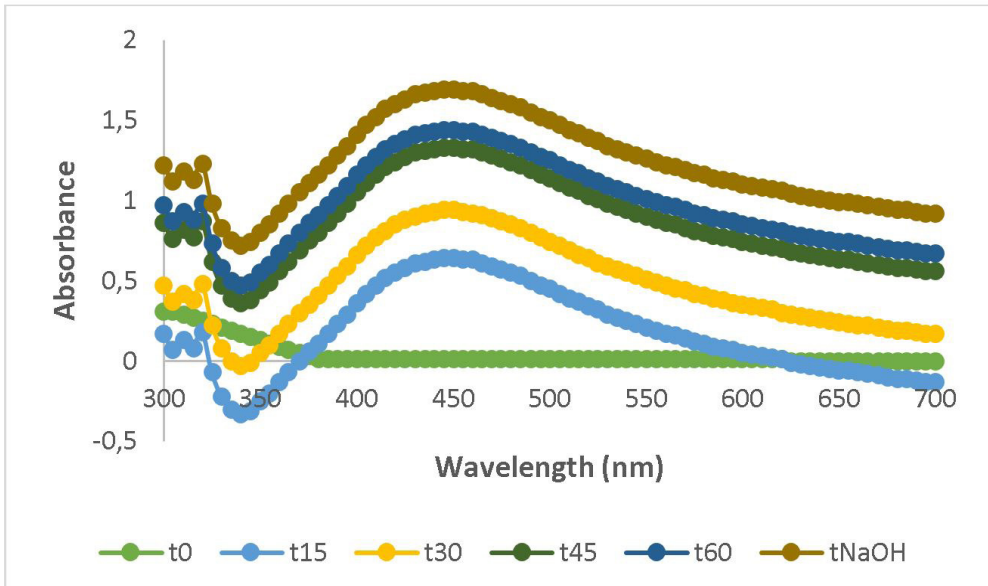

Gambar 2. Absorbansi larutan seiring pertambahan waktu sampai setelah penambahan $\mathrm{NaOH}$ pada proses sintesis nanopartikel perak menggunakan ekstrak air Daun Sendok dengan konsentrasi $0,25 \%$ pada suhu $70^{\circ} \mathrm{C}$. 


\section{HASIL PENELITIAN}

Terbentuknya nanopartikel perak terdeteksi melalui adanya perubahan warna yang terjadi seiring waktu pemanasan yaitu dari kuning muda menjadi warna coklat kemerahan seperti ditunjukkan pada Gambar 1. Lebih jauh, terbentuknya nanopartikel perak juga dikonfirmasi dengan absorbansi larutan dengan Spektrofotometer UV-Vis pada panjang gelombang $445 \mathrm{~nm}$. Pembacaan absorbansi larutan dilakukan setiap 15 menit sampai 60 menit selama proses sintesis berlangsung. Setelah proses pemanasan selama 60 menit, larutan sampel ditambahkan $\mathrm{NaOH}$ 0,2 M sedikit demi sedikit sambil diamati perubahan warna yang terjadi, absorbansi larutan setelah penambahan $\mathrm{NaOH}$ diamati kembali untuk memantau pertambahan absorbansi yang mengindikasikan reaksi sintesis telah optimum. Perubahan absorbansi larutan seiring pertambahan waktu sampai setelah penambahan $\mathrm{NaOH}$ diamati menggunakan Spektrofotometer UV-Vis (Gambar 2).

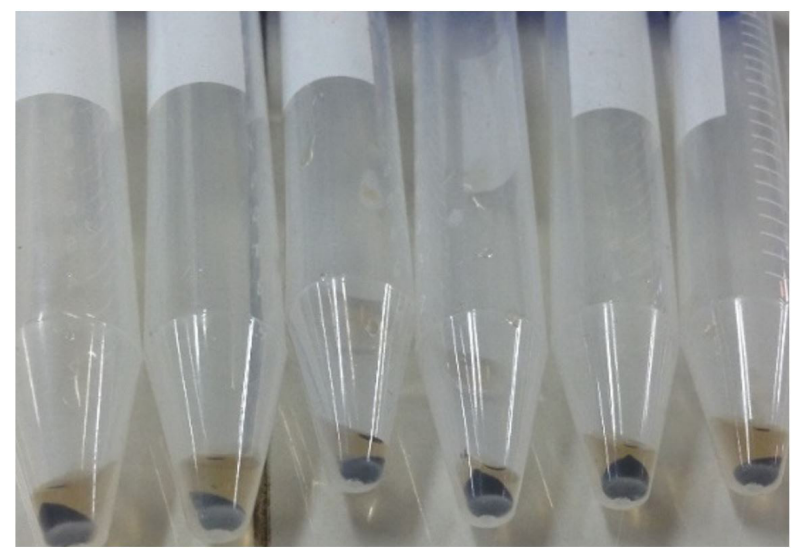

Gambar 3. Material tersuspensi dari proses sintesis nanopartikel perak

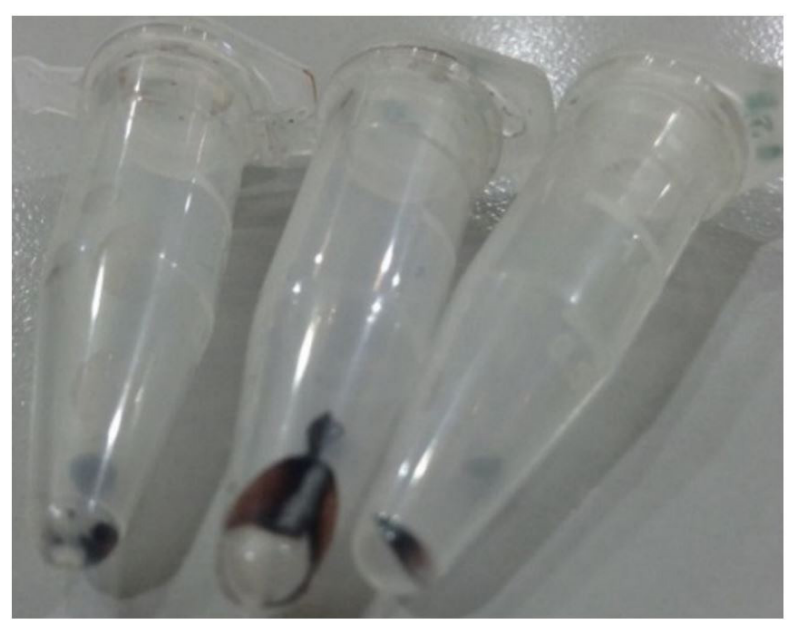

Gambar 4. Nanopartikel perak hasil sintesis
Setelah proses sintesis nanopartikel dilakukan, larutan sampel disentrifugasi $2000 \mathrm{rpm}$ selama 10 menit untuk memisahkan material tersuspensi dalam bentuk pellet (Gambar 3), kemudian nanopartikel perak yang terbentuk dikumpulkan dengan cara sentrifugasi larutan sintesis pada kecepatan tinggi. Pada percobaan ini, digunakan kecepatan $11.000 \mathrm{rpm}$. Sentrifugasi larutan dengan kecepatan tinggi ini menyebabkan nanopartikel perak mengendap ke dasar tabung, sehingga memungkinkan untuk dikumpulkan. Rendemen nanopartikel perak yang telah dikumpulkan kemudian dikeringkan dengan cara diletakkan di dalam eksikator. Rendemen nanopartikel perak yang dikumpulkan dalam bentuk padatan berada pada dasar tabung (Gambar 4).

Hasil Optimasi Konsentrasi Ekstrak dan Suhu Sintesis Terhadap Pembentukan Nanopartikel Perak Titik suhu yang dioptimasi adalah $60^{\circ} \mathrm{C}, 70^{\circ} \mathrm{C}$ dan $80^{\circ} \mathrm{C}$. Tiga titik konsentrasi yaitu $0,125 \% ; 0,25 \% ; 0,5 \%$ dioptimasi pada masing-masing suhu dan dilakukan replikasi sebanyak tiga kali. Tujuan akhir dari proses optimasi ini adalah untuk mendapatkan kombinasi suhu dan konsentrasi ekstrak optimum yang dapat menghasilkan rendemen nanopartikel perak yang paling baik. Hasil optimasi suhu sintesis dan konsentrasi ekstrak tanaman terhadap bobot rendemen dan kilau perak seperti ditunjukkan pada Tabel 1 .

Dari hasil optimasi ini, didapatkan rendemen terbesar berasal dari kombinasi konsentrasi ekstrak 0,25\% dan suhu sintesis $70^{\circ} \mathrm{C}$ dengan bobot rata-rata seberat 9,13 mg dari tiga kali replikasi. Selain itu, warna perak pada rendemen ditunjukkan pada semua titik, namun nampak paling jelas pada konsentrasi tanaman $0,125 \%$ dan $0,25 \%$ baik dilakukan pada suhu 60,70 maupun $80^{\circ} \mathrm{C}$. Grafik di bawah ini (Gambar 5) menunjukkan perbandingan rendemen yang dihasilkan dari masing-masing titik konsentrasi ekstrak tanaman dan suhu sintesis.

Penggunaan konsentrasi ekstrak $0,25 \%$ dan suhu sintesis $70^{\circ} \mathrm{C}$ menunjukkan rendemen yang paling besar dibandingkan dengan perpaduan konsentrasi ekstrak dan suhu lainnya. Pengamatan organoleptis berupa warna hasil rendemen juga menunjukkan hasil kilau perak yang nampak dengan jelas pada titik konsentrasi $0,25 \%$ pada semua suhu optimasi. Gambaran terbentuknya senyawa perak pada proses sintesis menggunakan konsentrasi ekstrak $0,25 \%$ dapat dilihat setelah penambahan $\mathrm{NaOH}$, dimana penambahan buffer $\mathrm{NaOH}$ dimaksudkan untuk meningkatkan reduction rate dalam pembentukan nanopartikel perak. Grafik absorbansi di bawah ini (Gambar 6) menggambarkan perbandingan nilai absorbansi nanopartikel perak yang terbentuk setelah penambahan $\mathrm{NaOH}$ dengan variasi suhu sintesis yang digunakan pada masing-masing konsentrasi ekstrak. 
Tabel 1. Hasil optimasi konsentrasi ekstrak tanaman dan suhu sintesis terhadap rendemen dan visualisasi hasil nanopartikel perak

\begin{tabular}{llll}
\hline \multicolumn{2}{c}{ Kondisi optimasi } & \multicolumn{2}{c}{ Parameter } \\
\hline $\begin{array}{l}\text { Konsentrasi ekstrak } \\
\text { tanaman (\%) }\end{array}$ & Suhu $\left({ }^{\circ} \mathbf{C}\right)$ & $\begin{array}{l}\text { Visualisasi Kilau } \\
\text { Perak* }\end{array}$ & Rendemen (mg) \\
\hline 0,125 & 60 & +++ & 5,43 \\
0,125 & 70 & +++ & 5,33 \\
0,125 & 80 & +++ & 4,70 \\
0,25 & 60 & +++ & 8,50 \\
0,25 & 70 & +++ & 9,13 \\
0,25 & 80 & +++ & 6,77 \\
0,5 & 60 & ++ & 7,37 \\
0,5 & 70 & ++ & 7,00 \\
0,5 & 80 & ++ & 6,27 \\
\hline
\end{tabular}

Tabel 2. Ukuran rata-rata nanopartikel perak pada masing-masing suhu sintesis dan konsentrasi ekstrak

\begin{tabular}{llcl}
\hline \multirow{2}{*}{$\begin{array}{l}\text { Suhu Sintesis } \\
\left({ }^{\circ} \mathrm{C}\right)\end{array}$} & \multicolumn{3}{c}{$\begin{array}{c}\text { Ukuran Partikel }(\mathbf{n m}) \\
\text { Rata-rata } \pm \text { SD dari 3 replikasi }\end{array}$} \\
\cline { 2 - 4 } & Ekstrak 0,125\% & Ekstrak 0,25\% & Ekstrak 0,5\% \\
\hline $\mathbf{6 0}$ & $146,467 \pm 1,436$ & $138,367 \pm 3,742$ & $482,633 \pm 36,341$ \\
$\mathbf{7 0}$ & $149,600 \pm 2,042$ & $129,200 \pm 4,104$ & $528,167 \pm 29,824$ \\
$\mathbf{8 0}$ & $174,867 \pm 7,433$ & $144,267 \pm 2,060$ & $676,267 \pm 147,107$ \\
\hline
\end{tabular}

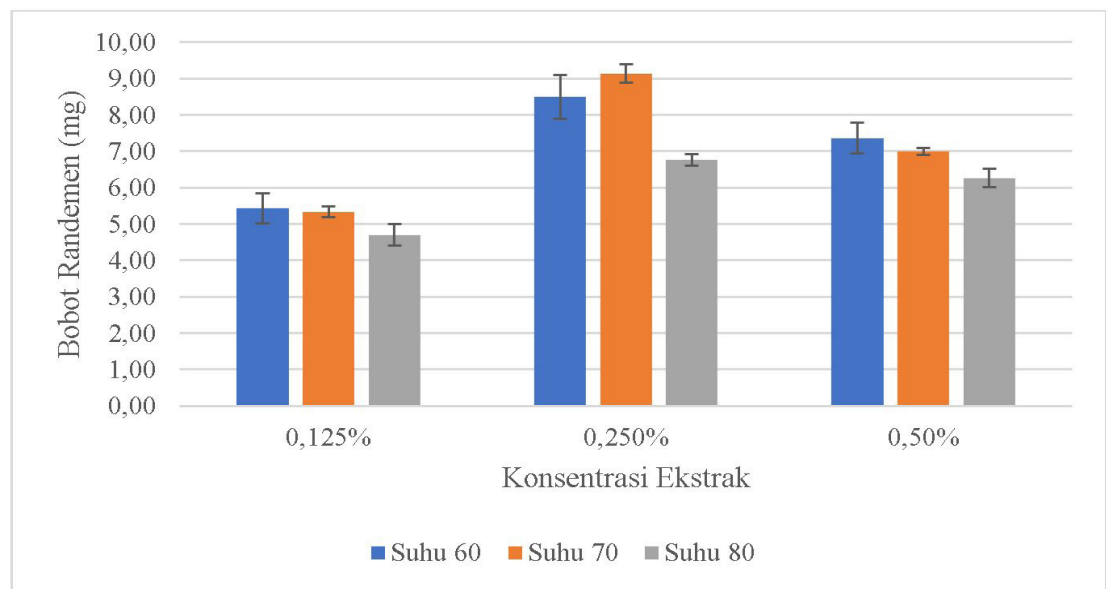

Gambar 5. Grafik hasil rendemen sintesis nanopartikel perak pada masing-masing konsentrasi ekstrak dan suhu

Hasil Karakterisasi Ukuran dan Distribusi Ukuran Nanopartikel Perak menggunakan Dynamic Light Scattering (DLS)

Masing-masing hasil sintesis dengan konsentrasi tanaman $0,125 \% ; 0,25 \% ; 0,5 \%$ yang disintesis pada suhu $60^{\circ} \mathrm{C}, 70^{\circ} \mathrm{C}$ dan $80^{\circ} \mathrm{C}$, dianalisa ukuran dan distribusi ukuran partikelnya. Karakterisasi ukuran dan distribusi ukuran nanopartikel perak dilakukan menggunakan instrumen Dynamic Light Scattering
(DLS). Tabel 2 menampilkan rata-rata hasil pengukuran partikel pada masing-masing konsentrasi dan suhu dari 3 kali pembacaan dengan DLS. Dari hasil pengukuran dapat dilihat tren ukuran nanopartikel berbanding lurus dengan pertambahan suhu sintesis pada semua konsentrasi ekstrak tanaman, kecuali pada konsentrasi ekstrak $0,25 \%$ dimana rata-rata hasil pengukuran pada suhu $60^{\circ} \mathrm{C} ; 70^{\circ} \mathrm{C}$ dan $80^{\circ} \mathrm{C}$ berturut-turut adalah 138,367 $\pm 3,742 \mathrm{~nm} ; 129,200 \pm 4,104 \mathrm{~nm}$ dan $144,267 \pm 2,060$ 

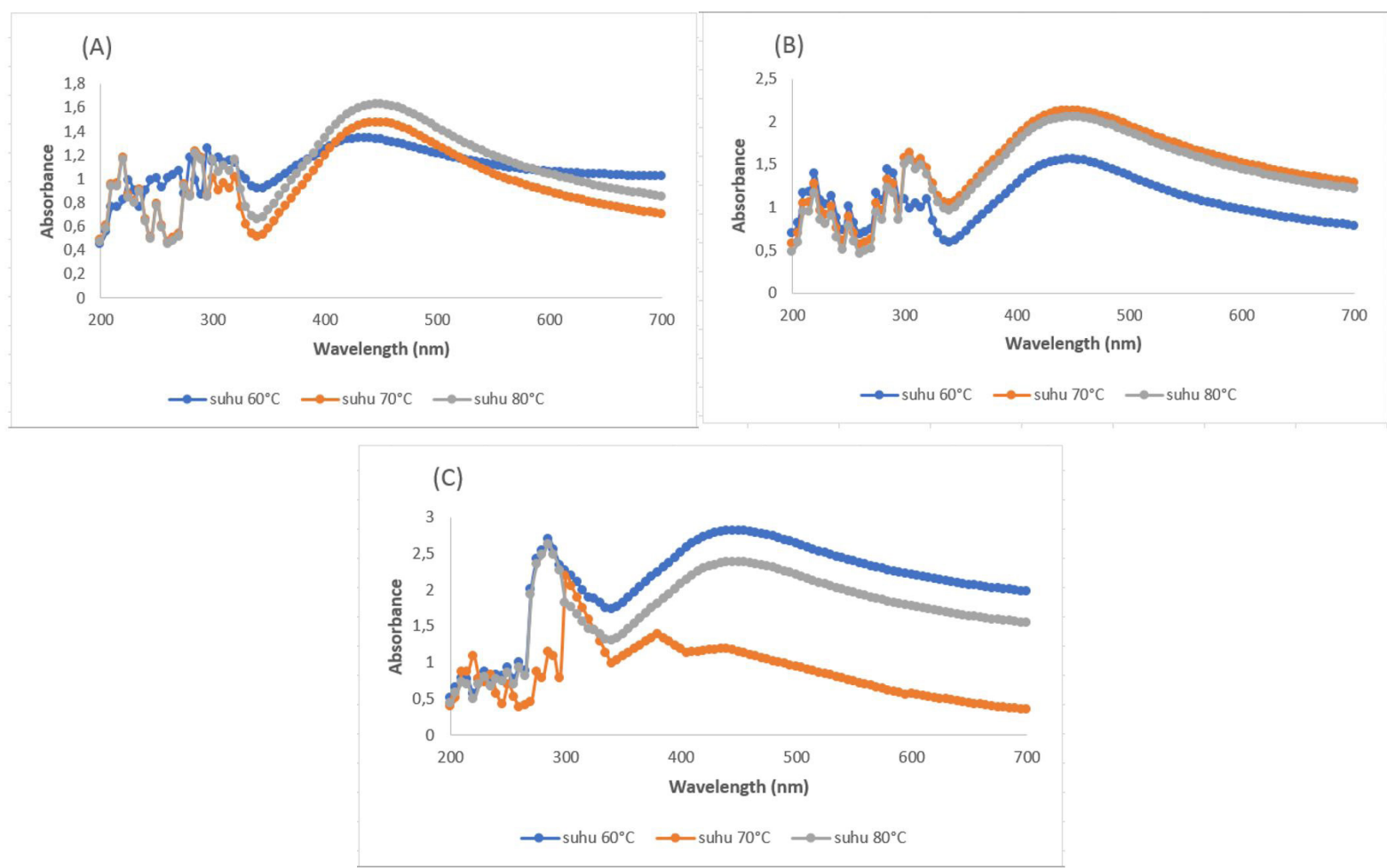

Gambar 6. Perbandingan absorbansi larutan pada masing-masing suhu dengan konsentrasi ekstrak (A) $0,125 \%$; (B) $0,25 \%$; dan (C) $0,5 \%$

Tabel 3. Nilai polydispersity index nanopartikel perak pada masing-masing suhu dan konsentrasi ekstrak

\begin{tabular}{llll}
\hline \multirow{2}{*}{$\begin{array}{c}\text { Suhu Sintesis } \\
\left({ }^{\circ} \mathrm{C}\right)\end{array}$} & \multicolumn{3}{c}{ Polydispersity Index } \\
\cline { 2 - 5 } & Ekstrak 0,125\% & Ekstrak 0,25\% & Ekstrak 0,5\% \\
\hline 60 & 0,2607 & 0,2420 & 0,3563 \\
70 & 0,2073 & 0,2500 & 0,2533 \\
80 & 0,2397 & 0,2467 & 0,2850 \\
\hline
\end{tabular}

nm. Pada konsentrasi ekstrak 0,125\% rata-rata hasil pengukuran pada masing-masing suhu $60^{\circ} \mathrm{C} ; 70^{\circ} \mathrm{C}$ dan $80^{\circ} \mathrm{C}$ adalah $146,467 \pm 1,436 \mathrm{~nm} ; 149,600 \pm 2,042 \mathrm{~nm}$

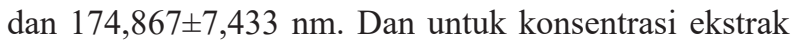
$0,5 \%$ dengan kombinasi suhu yang sama diperoleh ukuran partikel masing-masing 482,633 $\pm 36,341 \mathrm{~nm}$; $528,167 \pm 29,824 \mathrm{~nm}$ dan 676,267 $\pm 147,107 \mathrm{~nm}$. Dari hasil ini diketahui bahwa ukuran partikel terkecil didapatkan dari kombinasi konsentrasi ekstrak tanaman $0,25 \%$ dan suhu sintesis $70^{\circ} \mathrm{C}$.

Parameter distribusi ukuran partikel ditentukan dalam nilai polydispersity index (PDI). Dari hasil pengukuran dengan DLS, PDI dengan nilai terkecil hasil rata-rata dari 3 kali pengulangan diperoleh pada sintesis dengan konsentrasi ekstrak tanaman $0,125 \%$ pada suhu $70^{\circ} \mathrm{C}$, yaitu sebesar 0,2073 . Nilai PDI hasil pembacaan dengan DLS dapat dilihat pada Tabel 3.

Gambaran distribusi ukuran partikel dari nanopartikel perak hasil sintesis dengan konsentrasi ekstrak tanaman
$0,25 \%$ pada suhu $70^{\circ} \mathrm{C}$ yang menunjukkan ukuran partikel paling kecil dibandingkan kombinasi konsentrasi ekstrak dan suhu sintesis lainnya, dapat dilihat pada Gambar 7.

\section{Hasil Karakterisasi Menggunakan Scanning Electron Microscopy (SEM)}

Scanning Electron Microscope (SEM) digunakan untuk mengamati ukuran dan morfologi dari nanopartikel perak. Berdasarkan hasil pengamatan rendemen nanopartikel perak hasil sintesis menggunakan konsentrasi ekstrak $0,25 \%$ pada suhu $70^{\circ} \mathrm{C}$, dapat dilihat bahwa morfologi nanopartikel perak adalah berbentuk spherical (Gambar 8).

Hasil Analisa Senyawa Perak pada Nanopartikel hasil Green Synthesis Menggunakan Instrumen X-Ray Difraction (X-RD)

Untuk mengkonfirmasi adanya gugus senyawa perak dalam randeman nanopartikel yang dihasilkan dari proses sintesis, dilakukan analisa dengan instrumen X-RD untuk melihat pola difraktogram dari rendemen yang 


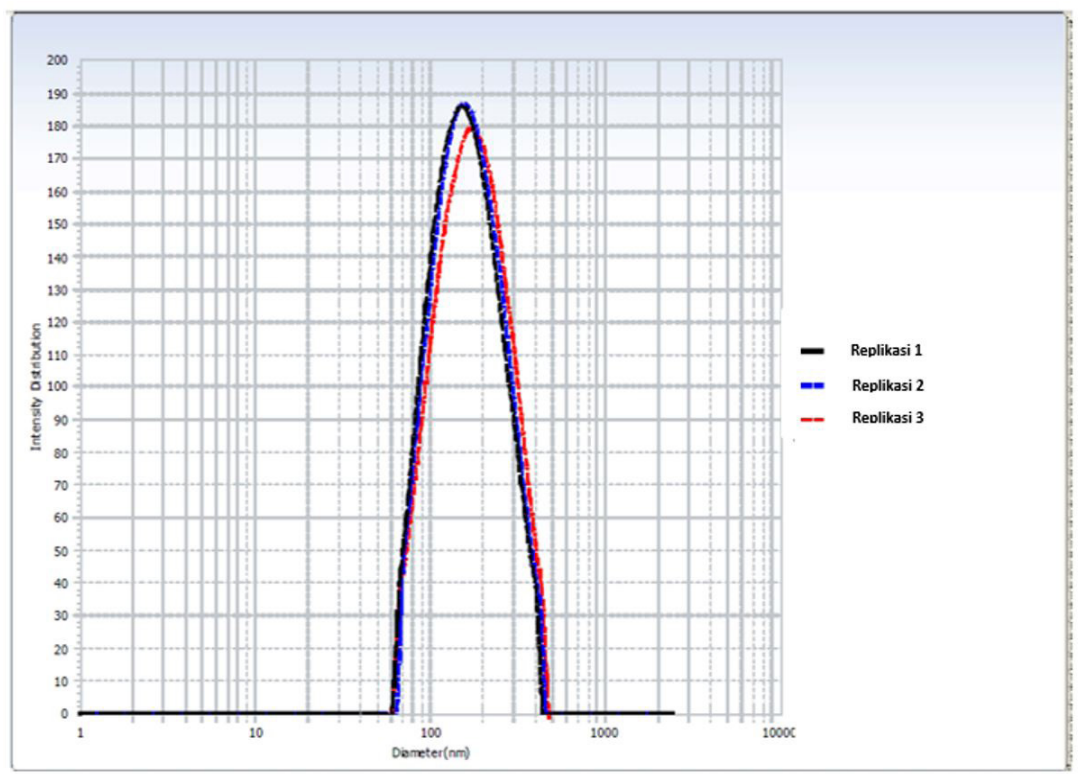

Gambar 7. Grafik distribusi ukuran partikel randemen nanopartikel perak hasil sintesis dengan ekstrak tanaman konsentrasi $0,25 \%$ pada $\mathrm{Suhu} 70^{\circ} \mathrm{C}$.

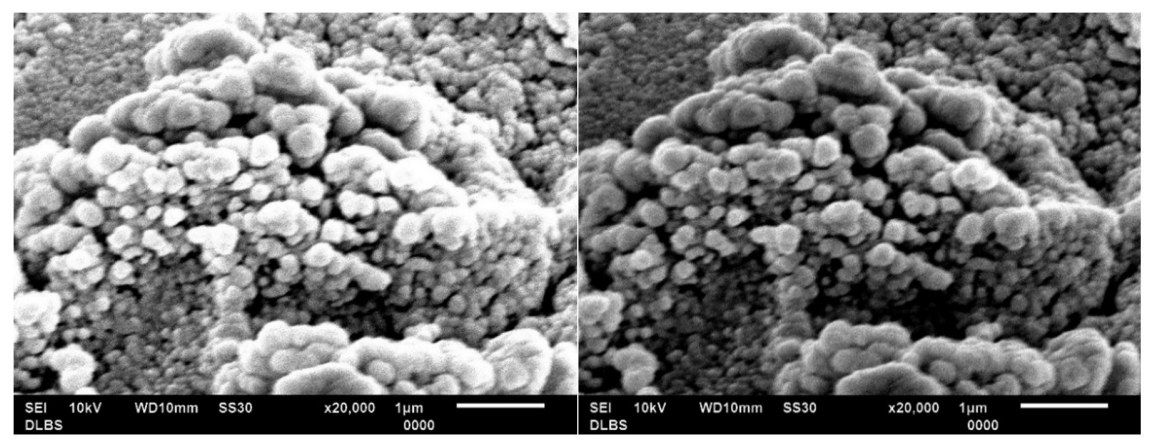

Gambar 8 Hasil karakterisasi nanopartikel perak menggunakan SEM pada Pengamatan dengan perbesaran 20.000x

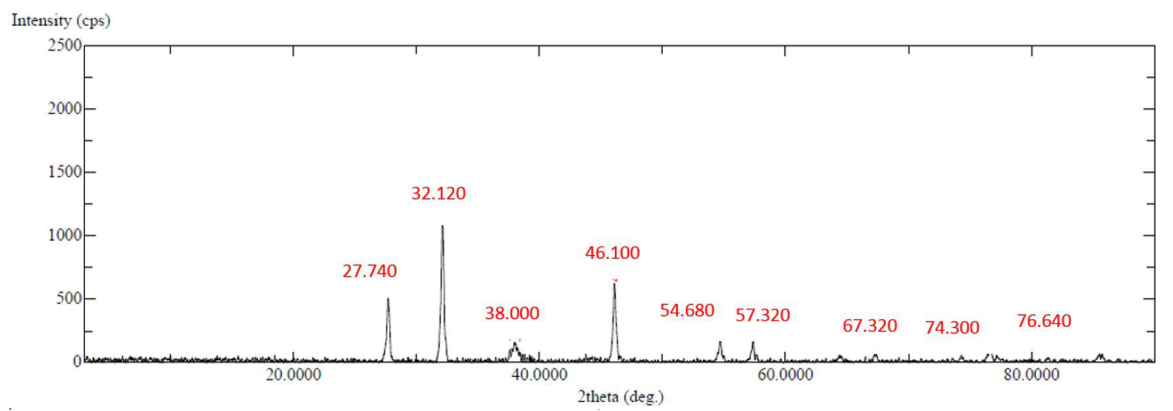

Gambar 9. Difraktogram X-Ray nanopartikel perak

terbentuk untuk kemudian dibandingkan dengan standard difraktogram senyawa perak. Gambar 9 menampilkan pola difraksi X-ray nanopartikel perak yang disintesis menggunakan ekstrak air Plantago major konsentrasi $0,25 \%$ pada suhu $70^{\circ} \mathrm{C}$. Dari hasil analisa difragtogram dapat dinyatakan bahwa rendemen nanopartikel yang dihasilkan mengandung senyawa perak, dilihat dari peak kristalin rendemen yang menghasilkan pola yang mirip dengan peak pada standar referensi. Puncak difraksi $2 \theta$ teramati pada $38,00^{\circ} ; 46,1^{\circ} ; 67,32^{\circ} ; 76,64^{\circ}$.
Profil pola difraktogram dengan jelas menggambarkan bahwa nanopartikel perak terdapat di dalam rendemen. Dibandingkan dengan standard (JCPDS) file no.:040783 (Swanson et al., 1955). Namun demikian, berdasarkan pengamatan pada pola yang dihasilkan, masih terdapat adanya peak yang menunjukkan adanya impurities pada rendemen, hal ini diprediksi bersumber dari proses sintesis nanopartikel yang menggunakan tanaman dan juga zat katalis seperti $\mathrm{NaOH}$. Impurities yang terbentuk contohnya senyawa $\mathrm{Ag}_{2} \mathrm{O}$ yang terbaca pada $2 \Theta 27.720$; 32.120 dan 54.680 
Tabel 4. Hasil pengukuran zona hambat pada pengujian aktivitas antibakteri

\begin{tabular}{|c|c|c|c|c|}
\hline \multirow[t]{2}{*}{ No. } & \multirow[t]{2}{*}{ Sampel Uji } & \multicolumn{2}{|c|}{$\begin{array}{l}\text { Zona Hambat } \\
(\mathbf{m m})\end{array}$} & \multirow{2}{*}{$\begin{array}{l}\text { Rata-rata } \\
(\mathrm{mm})\end{array}$} \\
\hline & & 1 & 2 & \\
\hline \multicolumn{5}{|c|}{ Bakteri: Pseudomonas aeruginosa } \\
\hline 1. & Kontrol Positif (Gentamisin 100 ppm) & 6,37 & 6,98 & 6,68 \\
\hline 2. & Kontrol Negatif (Air Steril) & 0 & 0 & 0 \\
\hline 3. & Ekstrak Daun Sendok 0,25\% & 0 & 0 & 0 \\
\hline 4. & Nanopartikel Ag 0,25\% & 4,71 & 5,55 & 5,13 \\
\hline 5. & Larutan $\mathrm{AgNO}_{3} 1 \mathrm{mmol}$ & 4,74 & 4,72 & 4,73 \\
\hline \multicolumn{5}{|c|}{ Bakteri: Escherichia coli } \\
\hline 1. & Kontrol Positif (Gentamisin 100 ppm) & 5,51 & 5,14 & 5,33 \\
\hline 2. & Kontrol Negatif (Air Steril) & 0 & 0 & 0 \\
\hline 3. & Ekstrak Daun Sendok 0,25\% & 0 & 0 & 0 \\
\hline 4. & Nanopartikel Ag 0,25\% & 6,28 & 6,07 & 6,18 \\
\hline 5. & Larutan $\mathrm{AgNO}_{3} 1 \mathrm{mmol}$ & 5,17 & 4,49 & 4,83 \\
\hline \multicolumn{5}{|c|}{ Bakteri: Staphylococcus aureus } \\
\hline 1. & Kontrol Positif (Kloramfenikol 250 ppm) & 6,53 & 5,70 & 6,12 \\
\hline 2. & Kontrol Negatif (Air Steril) & 0 & 0 & 0 \\
\hline 3. & Ekstrak Daun Sendok 0,25\% & 0 & 0 & 0 \\
\hline 4. & Nanopartikel Ag 0,25\% & 6,96 & 7,42 & 7,19 \\
\hline 5. & Larutan $\mathrm{AgNO}_{3} 1 \mathrm{mmol}$ & 6,02 & 5,36 & 5,69 \\
\hline
\end{tabular}

Hasil Pengujian Aktivitas Antibakteri dengan Metode Paper Disc

Pengujian aktivitas antibakteri dilakukan dengan metode difusi menggunakan paper disc pada bakteri gram negatif dan positif. Bakteri yang digunakan adalah Pseudomonas aeruginosa, Escherichia coli, untuk bakteri gram negatif dan Staphylococcus aureus untuk bakteri gram positif. Sampel nanopartikel perak yang diuji adalah rendemen hasil sintesis dengan konsentrasi ekstrak tanaman $0,25 \%$ dengan suhu sintesis $70^{\circ} \mathrm{C}$. Pada pengujian aktivitas antibakteri terhadap bakteri gram negatif, sebagai kontrol positif digunakan antibiotik Gentamicyn $(100 \mu \mathrm{g} / \mathrm{mL})$. Sedangkan, untuk bakteri gram positif digunakan Kloramfenikol $(250 \mu \mathrm{g} / \mathrm{mL})$. Kontrol negatif adalah aquademineralisata steril. Dalam pengujian aktivitas antibakteri ini, larutan $\mathrm{AgNO}_{3} 1$ mmol dan ekstrak air tanaman daun sendok konsentrasi $0,25 \%$ juga diuji aktivitas antibakterinya dan digunakan sebagai pembanding. Kedua sampel ini merupakan bahan atau komposisi awal pembentuk nanopartikel perak, sehingga perlu dianalisa aktivitas antibakteri kedua sampel ini untuk dibandingkan, apakah ada peningkatan daya hambat antibakteri setelah kedua komponen ini membentuk nanopartikel perak. Proses inkubasi dilakukan pada suhu $37^{\circ} \mathrm{C}$ selama 48 jam. Setelah 48 jam inkubasi, dilakukan pengukuran diameter daerah hambat menggunakan jangka sorong. Tabel 4 menunjukkan hasil pengukuran zona hambat pada hasil pengujian aktivitas antibakteri.

Pada pengujian diperoleh bahwa larutan $\mathrm{AgNO}_{3}$ menunjukkan adanya zona hambat pada ketiga bakteri uji. Namun, zona hambat yang dihasilkan lebih kecil dibandingkan zona hambat yang dihasilkan oleh rendemen nanopartikel perak. Pada pengujian terhadap bakteri gram positif, Staphylococcus aureus, zona hambat yang dihasilkan oleh larutan $\mathrm{AgNO}_{3}$ adalah 5,69 mm, sedangkan zona hambat AgNPs adalah 7,19. Artinya terdapat peningkatan nilai zona hambat sebesar $27,85 \%$ pada pengujian menggunakan nanopartikel perak dibandingkan larutan $\mathrm{AgNO}_{3}$. Hasil serupa juga ditunjukan pada pengujian aktivitas antibakteri terhadap 


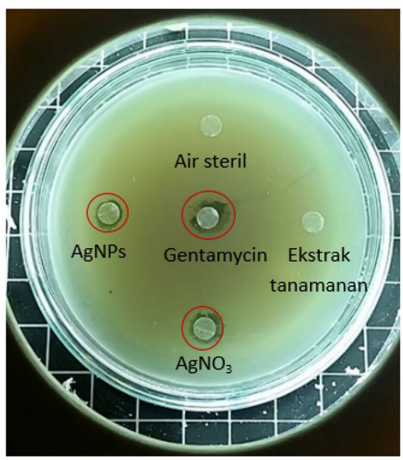

(A)

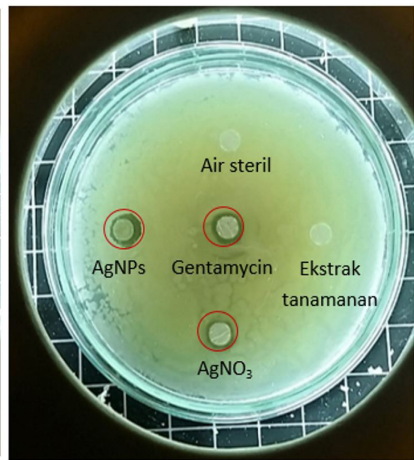

(B)

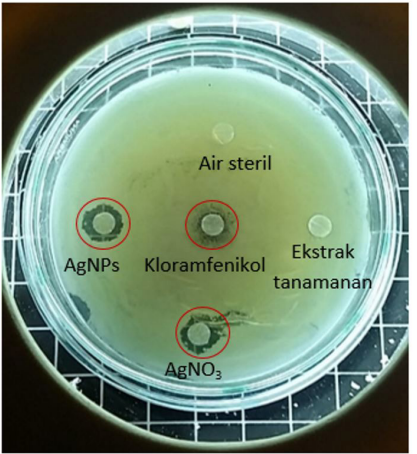

(C)

Gambar 10. Pengujian aktivitas antibakteri nanopartikel perak dengan metode Paper Disc. Pengujian pada Bakteri (A) Pseudomonas aeruginosa; (B) Escherichia coli; (C) Staphylococcus aureus

bakteri gram negatif, Pseudomonas aeruginosa dan Escherichia coli, dimana terjadi peningkatan nilai zona hambat pertumbuhan bakteri, masing-masing sebesar $17,58 \%$ dan 26,36\%. Sebaliknya, sampel ekstrak tanaman daun sendok tidak menunjukkan aktivitas antibakteri, dimana dalam pengujian sampel tanaman daun sendok tidak menunjukkan adanya zona hambat terhadap pertumbuhan bakteri. Gambar 10 merupakan hasil pengujian aktivitas antibakteri dengan metode difusi menggunakan paper disc.

\section{PEMBAHASAN}

Mekanisme reduksi oleh kandungan senyawa dalam tanaman terhadap garam logam, dapat dijelaskan dalam beberapa tahap. Fase pertama adalah fase dimana terjadi reduksi ion logam dan nukleasi dari atom logam yang telah tereduksi, dilanjutkan dengan koalisi spontan dari sejumlah nanopartikel yang berdekatan membentuk partikel dengan ukuran yang lebih besar, seiring dengan peningkatan stabilitas termodinamik dari nanopartikel, proses ini mengacu pada prinsip Ostwal ripening. Fase akhir yaitu dimana bentuk akhir dari nanopartikel terbentuk (Keat et al., 2015).

Parameter awal yang menjadi tolak ukur formasi nanopartikel perak seiring pertambahan waktu sintesis yaitu dengan mengamati perubahan warna larutan. Perubahan warna larutan terjadi dari warna kuning pucat menjadi kuning kecokatan, sampai menjadi coklat kemerahan. Perubahan warna larutan pada sintesis nanopartikel perak terjadi karena surface plasmon resonance dan reduksi dari ion perak (Erjaee et al., 2017). Lebih jauh, formasi nanopartikel perak juga dikonfirmasi dengan pembacaan absorbansi larutan menggunakan instrumen Spektrofotometer UV-Vis, absorbansi nanopartikel perak pada percobaan ini berada pada panjang gelombang $445 \mathrm{~nm}$. Serapan absorbansi pada panjang gelombang 400-450 nm diketahui merupakan nanopartikel perak $\left(\mathrm{Ag}^{0}\right)$, sedangkan serapan yang terbentuk pada panjang gelombang 370-400 nm merupakan ion perak $\left(\mathrm{Ag}^{+}\right)$(Oktaviani \& Amrullah, 2009). Dapat dilihat pada Gambar 2, absorbansi larutan bertambah seiring pertambahan waktu sintesis, hal ini menunjukkan rate reduction berbanding lurus dengan pertambahan waktu sintesis. Namun, pada menit ke-45 dan 60 dapat dilihat bahwa perubahan nilai absorbansi maupun perubahan warna larutan tidak lagi signifikan. Hal ini menandakan bahwa pada waktu tertentu rate reduction akan menjadi konstan, dimana tidak terjadi lagi formasi nanopartikel perak karena garam perak telah tereduksi seluruhnya (Verma \& Mehata, 2016).

Masing-masing rendemen hasil sintesis menggunakan berbagai kombinasi suhu dan konsentrasi tanaman, dianalisa bobot dan parameter organoleptis berupa kilau perak yg terbentuk. Kriteria ini adalah parameter awal untuk menentukan titik kombinasi yang paling baik dalam sintesis nanopartikel perak menggunakan ekstrak air daun sendok. Secara visual, kilau perak yang paling baik ditunjukkan pada rendemen hasil sintesis menggunakan konsentrasi ekstrak tanaman 0,125\% dan $0,25 \%$ pada semua suhu sintesis, dibandingkan rendemen hasil sintesis menggunakan konsentrasi ekstrak $0,5 \%$ pada semua suhu sintesis. Sedangkan rendemen terbaik dihasilkan dari sintesis menggunakan konsentrasi ekstrak $0,25 \%$ dengan suhu sintesis $70^{\circ} \mathrm{C}$, yaitu rata-rata seberat $9,13 \mathrm{mg}$ dari 3 kali replikasi.

Penentuan titik kombinasi konsentrasi ekstrak dan suhu sintesis terbaik dalam sintesis nanopartikel perak dilanjutkan dengan menguji ukuran dan distribusi ukuran partikel dari rendemen yang terbentuk, menggunakan instrumen DLS Nano - particle size analyzer. Ukuran dari nanopartikel hasil sintesis dipengaruhi oleh kinetika reaksi yang terjadi. Komposisi dari larutan/media berperan penting dalam menentukan kinetika reaksi dalam proses sintesis nanopartikel perak (Pourmortazavi et al., 2015). Berbagai parameter memiliki pengaruh terhadap kinetika reaksi tersebut, antara lain konsentrasi 
ekstrak tanaman yang digunakan sebagai agen pereduksi dan suhu yang digunakan dalam proses sintesis. Perubahan komposisi pada parameter-parameter yang digunakan, dapat menghasilkan karakter nanopartikel yang berbeda (Erjaee et al., 2017).

Hasil pengukuran rendemen nanopartikel perak dengan masing-masing kombinasi suhu dan konsentrasi ekstrak dirangkum dalam Tabel 2. Secara umum dapat dilihat bahwa, ukuran terkecil diperoleh dari hasil sintesis menggunakan konsentrasi ekstrak 0,25\% jika dibandingkan dengan konsentrasi $0,125 \%$ dan $0,5 \%$ pada masing-masing kombinasi suhu $60^{\circ} \mathrm{C}, 70^{\circ} \mathrm{C}$ dan $80^{\circ} \mathrm{C}$. Dari hasil ini dapat disimpulkan, ukuran partikel lebih kecil didapatkan saat pertambahan konsentrasi ekstrak dari $0,125 \%$ menjadi $0,25 \%$, namun sebaliknya dengan meningkatkan konsentrasi ekstrak lebih jauh menjadi 0,5\% ukuran partikel menjadi bertambah besar. Temuan ini mendukung kesimpulan yang diperoleh pada studi yang dilakukan oleh Purmortazavi et al. pada penelitiannya yang berjudul "Procedure optimization for green synthesis of silver nanoparticles by aqueous extract of Eucalyptus oleosa", pada penelitian ini, peneliti melakukan optimasi pada berbagai parameter dalam green synthesis nanopartikel perak menggunakan ekstrak air dari tanaman Eucalyptus oleosa. Parameter yang dioptimasi antara lain adalah konsentrasi ekstrak tanaman, konsentrasi $\mathrm{AgNO}_{3}$, waktu sintesis, dan suhu ekstraksi tanaman. Dari penelitian terhadap pengaruh konsentrasi ekstrak tanaman yang digunakan, ditemukan bahwa, meningkatkan konsentrasi tanaman dari 1\% menjadi 5\% dapat menurunkan ukuran dari nanopartikel yang dihasilkan. Sementara dengan meningkatkan konsentrasi tanaman sampai 10\% justru menghasilkan ukuran nanopartikel yang lebih besar (Pourmortazavi et al., 2015).

Variasi suhu pada penelitian ini, secara umum menunjukkan pengaruh berupa peningkatan ukuran partikel seiring pertambahan suhu. Kecuali pada percobaan menggunakan konsentrasi ekstrak 0,25\% dimana sintesis dengan suhu $70^{\circ} \mathrm{C}$ menghasilkan ukuran partikel yang lebih kecil dibandingkan yang disintesis pada suhu $60^{\circ} \mathrm{C}$. Disebutkan bahwa ukuran nanopartikel perak dapat diatur dengan melakukan variasi suhu sintesis (Tippayawat et al., 2016). Suhu tinggi dibutuhkan untuk membantu proses reduksi (Liu et al., 2012). Nukleasi dan formasi dari nanopartikel perak tergantung pada suhu reaksi yang digunakan (Tippayawat et al., 2016). Namun di sisi lain, perlu juga mempertimbangkan kestabilan komposisi kandungan ekstrak. Paparan suhu yang terlampau tinggi pada komponen ekstrak yang termolabil dapat mengakibatkan degradasi atau kerusakan senyawa yang berfungsi sebagai agen pereduksi dalam sintesis nanopartikel perak.
Selain ukuran partikel, distribusi ukuran partikel dari rendemen nanopartikel perak yang disintesis pada masing-masing kombinasi suhu dan konsentrasi ekstrak, merupakan parameter lain yang juga diuji menggunakan instrumen DLS Nano. Hasil pengukuran ditunjukkan dalam Poly Dispersity Index (PDI). Suatu sampel dikatakan monodisper jika nilai PDI kurang dari 0,1 (Hughes et al., 2015). Pada penelitian ini, nilai PDI berkisar pada rentang 0,21-0,36. Dengan nilai PDI terkecil didapatkan dari rendemen hasil sintesis menggunakan konsentrasi ekstrak $0,125 \%$ pada suhu $70^{\circ} \mathrm{C}$, yaitu sebesar 0,21. Dapat disimpulkan dari penelitian ini bahwa seluruh rendemen hasil sintesis dari masing-masing kombinasi konsentrasi ekstrak dan suhu sintesis, tergolong partikel polidispers. Karena nilai PDI yang dihasilkan di atas 0,1 .

Hasil optimasi terhadap parameter visual, bobot dan ukuran partikel rendemen yang dihasilkan dari masingmasing kombinasi konsentrasi ekstrak dan suhu sintesis, menunjukkan bahwa kombinasi antara konsentrasi ekstrak $0,25 \%$ dan suhu sintesis $70^{\circ} \mathrm{C}$ merupakan titik kombinasi yang paling optimum. Karakterisasi morfologi rendemen nanopartikel perak dilakukan dengan menggunakan instrumen Scanning Electron Microscopy (SEM), hasil pengamatan menunjukkan rendemen nanopartikel perak hasil sintesis dengan ekstrak air tanaman daun sendok dengan konsentrasi $0,25 \%$ pada suhu $70^{\circ} \mathrm{C}$ memiliki bentuk spherical, seperti yang ditampilkan pada Gambar 8. Bentuk dan morfologi rendemen nanopartikel dapat bervariasi, tergantung dari ekstrak tanaman yang digunakan.

Selain karakterisasi morfologi rendemen nanopartikel perak untuk dapat melihat bentuk dari rendemen hasil sintesis, karakterisasi untuk membuktikan kandungan senyawa perak dalam rendemen hasil sintesis juga perlu dilakukan. Spektrum XRD direkam untuk mengkonfirmasi struktur kristal dari nanopartikel perak yang terbentuk, untuk dibandingkan dengan standard. Puncak difraksi $2 \theta$ teramati pada $38,00^{\circ}$; $46,1^{\circ} ; 67,32^{\circ} ; 76,64^{\circ}$. Profil pola difraktogram dengan jelas menggambarkan bahwa nanopartikel perak terdapat di dalam rendemen. Dibandingkan dengan standard (JCPDS) file no.:040783 (Swanson et al., 1955). Berdasarkan pola difraktrogram yang terbentuk dapat dikatakan masih terdapat impurities seperti $\mathrm{Ag}_{2} \mathrm{O}$ yang terbaca pada $2 \theta$ yaitu $27,72^{\circ} ; 32,12^{\circ}$.

Nanopartikel perak yang diperoleh kemudian diuji aktivitas antibakteri terhadap bakteri gram positif dan negatif, yaitu Pseudomonas aeruginosa, Escherichia coli, untuk bakteri gram negatif dan Staphylococcus aureus untuk bakteri gram positif. Hasil pengujian menunjukkan bahwa nanopartikel perak memiliki aktivitas antibakteri 
terhadap ketiga bakteri uji, dengan aktivitas sedang. Bahkan pada pengujian dengan bakteri Staphylococcus aureus dan Escherichia coli, didapati bahwa zona hambat nanopartikel perak lebih tinggi masing-masing sebesar $6,58 \%$ dan 13,97\% dibandingkan zona hambat yang dihasilkan oleh antibiotik yang digunakan sebagai kontrol positif, yaitu Kloramfenikol untuk pengujian dengan bakteri Staphylococcus aureus dan gentamicin sulfat untuk bakteri Escherichia coli.

Dalam pengujian aktivitas antibakteri ini, larutan $\mathrm{AgNO}_{3}$ $1 \mathrm{mmol}$ dan ekstrak air tanaman daun sendok konsentrasi $0,25 \%$ juga diuji aktivitas antibakterinya dan digunakan sebagai pembanding. Kedua sampel ini merupakan komposisi awal pembentuk nanopartikel perak, sehingga perlu dianalisa aktivitas antibakteri kedua sampel ini, untuk dibandingkan, apakah ada peningkatan daya hambat antibakteri setelah setelah kedua komponen ini membentuk nanopartikel perak. Pada pengujian diperoleh bahwa larutan $\mathrm{AgNO}_{3}$ menunjukkan adanya zona hambat pada ketiga bakteri uji. Namun, zona hambat yang dihasilkan lebih kecil dibandingkan zona hambat yang dihasilkan oleh rendemen nanopartikel perak. Pada pengujian terhadap bakteri Pseudomonas aeruginosa, zona hambat yang dihasilkan oleh larutan $\mathrm{AgNO}_{3}$ adalah 4,73 mm, sedangkan zona hambat AgNPs adalah 5,13. Artinya terdapat peningkatan nilai zona hambat sebesar $17,58 \%$ pada pengujian menggunakan nanopartikel perak dibandingkan larutan $\mathrm{AgNO}_{3}$. Hasil serupa juga ditunjukkan pada pengujian aktivitas antibakteri terhadap bakteri Staphylococcus aureus dan Escherichia coli, dimana terjadi peningkatan ukuran zona hambat pertumbuhan bakteri, masing-masing sebesar $27,85 \%$ dan 26,36\%. Sebaliknya, sampel ekstrak tanaman daun sendok tidak menunjukkan aktivitas antibakteri, dimana dalam pengujian sampel tanaman daun sendok tidak menunjukkan adanya zona hambat terhadap pertumbuhan bakteri.

Beberapa studi telah dilakukan untuk meneliti aktivitas antibakteri dari tanaman daun sendok. Shariffa et al melakukan studi yang membandingkan aktivitas antibakteri antara ekstrak methanol, etanol dan ekstrak air tanaman daun sendok terhadap gram positif dan gram negatif bakteri, yaitu Staphylococcus aureus dan Escherichia coli. Hasil penelitian menunjukkan bahwa ekstrak methanol memiliki aktivitas antibakteri terhadap bakteri uji, yang dinyatakan dalam nilai MIC sebesar $100 \mathrm{mg} / \mathrm{ml}$ terhadap bakteri Staphylococcus aureus dan $120 \mathrm{mg} / \mathrm{ml}$ terhadap bakteri Escherichia coli. Ekstrak ethanol juga menunjukkan aktivitas antibakteri terhadap bakteri Staphylococcus aureus dengan nilai MIC $200 \mathrm{mg} / \mathrm{ml}$ dan Escherichia coli dengan nilai MIC $140 \mathrm{mg} / \mathrm{ml}$. Ekstrak air daun sendok tidak menunjukkan aktivitas antibakteri terhadap kedua bakteri uji (Sharifa et al., 2008).
Menilik hasil studi yang dilakukan tersebut kemudian dapat dikatakan bahwa dalam penelitian Uji Aktivitas Antibakteri Nanopartikel Perak Hasil Green Synthesis Menggunakan Ekstrak Air Daun Sendok ini, tanaman daun sendok hanya bertindak sebagai komponen pereduksi perak nitrat menjadi ion perak, dan sebagai capping agent dalam pembentukan ion perak menjadi nanopartikel perak. Namun, ekstrak air daun sendok sendiri tidak memiliki aktivitas antibakteri terhadap bakteri uji.

\section{KESIMPULAN}

Green synthesis nanopartikel perak dapat dilakukan menggunakan ekstrak air daun sendok, dengan konsentrasi optimum $0,25 \%$ dan disintesis pada suhu $70^{\circ} \mathrm{C}$ sehingga menghasilkan nanopartikel perak dengan bobot rata-rata $9,13 \mathrm{mg}$, ukuran partikel rata-rata 129,200 $\mathrm{nm}$ dan nilai PDI 0,2500. Nanopartikel perak yang diperoleh menunjukkan bentuk sferis dan menunjukan pola difraktogram yang serupa dengan dfraktogran perak. Nanopartikel perak hasil green synthesis menggunakan ekstrak air daun sendok dengan konsentrasi $0,25 \%$ yang disintesis pada suhu $70^{\circ} \mathrm{C}$ memiliki aktivitas antibakteri terhadap bakteri gram negatif maupun gram positif, yaitu bakteri Pseudomonas aeruginosa, Escherichia coli, untuk bakteri gram negatif dan Staphylococcus aureus untuk bakteri gram positif dengan aktivitas yang sebanding dengan antibiotik pembandingnya.

\section{DAFTAR ACUAN}

Ahmed, M., AlSalhi, M. S., \& Siddiqui, M. K. J. (2010). Silver nanoparticle applications and human health. Clinica Chimica Acta, 411(23-24), 1841-1848. https:// doi.org/10.1016/j.cca.2010.08.016

Erjaee, H., Rajaian, H., \& Nazifi, S. (2017). Synthesis and characterization of novel silver nanoparticles using Chamaemelum nobile extract for antibacterial application. Advances in Natural Sciences: Nanoscience and Nanotechnology, 8(2), aa690b. https://doi. org/10.1088/2043-6254/aa690b

Hughes, J. M., Budd, P. M., Grieve, A., Dutta, P., Tiede, K., \& Lewis, J. (2015). Highly monodisperse, lanthanidecontaining polystyrene nanoparticles as potential standard reference materials for environmental "nano" fate analysis. Journal of Applied Polymer Science, 132(24). https://doi.org/10.1002/app.42061

Iravani, S., Korbekandi, H., Mirmohammadi, S. V, \& Zolfaghari, B. (2014). Synthesis of silver nanoparticles : chemical, physical and biological methods, 9, 385-406. 
Keat, C. L., Aziz, A., Eid, A. M., \& Elmarzugi, N. A. (2015). Biosynthesis of nanoparticles and silver nanoparticles. Bioresources and Bioprocessing, 2(1), 47. https://doi.org/10.1186/s40643-015-0076-2

Kim, Y. (2015). Biogenic silver and gold nanoparticles synthesized using red ginseng root extract, and their applications. Artificial Cells, Nanomedicine, and Biotechnology, (April). https://doi.org/10.3109/216914 01.2015.1008514

Kim, Y., Yang, D., Singh, P., Kim, Y., \& Zhang, D. (2016). Biological Synthesis of Nanoparticles from Plants and Microorganisms, (November). https://oi. org/10.1016/j.tibtech.2016.02.006

Liu, Z., Xing, Z., Zu, Y., Tan, S., Zhao, L., Zhou, Z., $\&$ Sun, T. (2012). Synthesis and characterization of L-histidine capped silver nanoparticles. Materials Science and Engineering C, 32(4), 811-816. https://doi. org/10.1016/j.msec.2012.01.031

Mahmood, A. ., \& M.E, P. (2006). Wound Healing Activities of PM Leaf Extract in rats. International Journal Topical Medicine.

Mishra, M., Kumar, H., \& Tripathi, K. (2008). Diabetic Delayed Wound Healing And The Role of Silver, 3(2), 49-54.

Oktaviani, D. T., F., D. C., \& Amrullah, A. (2009). Sintesis Nano Ag Dengan Metode Reduksi Kimia, (1), $101-114$.

Parashar, V., Parashar, R., Sharma, B., \& Pandey, A. C. (2009). Parthenium Leaf Extract Mediated Synthesis of Silver Nanoparticles: A Novel Approach Towards Weed Utilization, 4(1), 45-50.

Pourmortazavi, S. M., Taghdiri, M., Makari, V., \& Rahimi-Nasrabadi, M. (2015). Procedure optimization for green synthesis of silver nanoparticles by aqueous extract of Eucalyptus oleosa. Spectrochimica Acta - Part A: Molecular and Biomolecular Spectroscopy, 136(PC), 1249-1254. https://doi.org/10.1016/j.saa.2014.10.010
Sharifa, A. A., Neoh, Y. L., Iswadi, M. I., Khairul, O., Halim, M. A., Jamaludin, M., Hing, H. L. (2008). Effects of methanol, ethanol and aqueous extract of Plantago major on gram positive bacteria, gram negative bacteria and yeast. Annals of Microscopy, 8, 41-44.

Singh, P., Kim, Y. J., Wang, C., Mathiyalagan, R., ElAgamy Farh, M., \& Yang, D. C. (2016). Biogenic silver and gold nanoparticles synthesized using red ginseng root extract, and their applications. Artificial Cells, Nanomedicine and Biotechnology, 44(3), 811-816. https://doi.org/10.3109/21691401.2015.1008514

Swanson, H. E., Gilfrich, N. T., \& Ugrinic, G. M. (1955). Standard X-Ray Diffraction Powder Patterns. U.S. Government Printing Office, Circular of the National Bureau of Standards 539, 26. https://doi.org/10.1524/ zkri.1970.131.1-6.159

Tian, J., Wong, K. K. Y., Ho, C., Lok, C., Yu, W., Che, C., ... Tam, P. K. H. (2007). Topical Delivery of Silver Nanoparticles Promotes Wound Healing, 129-136. https://doi.org/10.1002/cmdc.200600171

Tippayawat, P., Phromviyo, N., Boueroy, P., \& Chompoosor, A. (2016). Green synthesis of silver nanoparticles in aloe vera plant extract prepared by a hydrothermal method and their synergistic antibacterial activity. PeerJ, 4, e2589. https://doi.org/10.7717/ peerj. 2589

Verma, A., \& Mehata, M. S. (2016). Controllable synthesis of silver nanoparticles using Neem leaves and their antimicrobial activity. Journal of Radiation Research and Applied Sciences, 9(1), 109-115. https:// doi.org/10.1016/j.jrras.2015.11.001 